\title{
Obituary
}

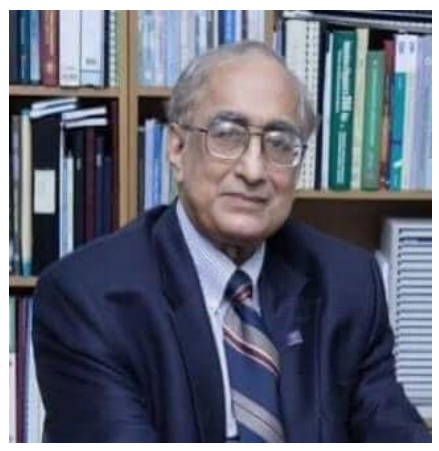

\section{Late National Professor Dr. Jamilur Reza Choudhury}

(1943-2020)

National Professor Dr. Jamilur Reza Choudhury was an internationally recognized civil engineer, educationist, researcher, and administrator. He was the most eminent personality in the engineering community of Bangladesh who made a great impact on science and technical education, engineering profession, and national development, particularly development of the infrastructure and IT sectors of Bangladesh.

Prof. J R Choudhury was born to Mrs. Hayatun Nessa Choudhury (1922-2010) and Engr. Abid Reza Choudhury (1905-1991) in Sylhet on $15^{\text {th }}$ November 1943. He had his early education in Mymensingh Zilla School and later moved to Dhaka where he attended Nawabpur Government High School and St. Gregory's High School and completed his matriculation in 1957. He completed his intermediate education from Dhaka College in 1959. Prof. Choudhury earned his bachelor's degree in Civil Engineering from EPUET (Present BUET) in 1963 securing first class first position with honors and joined the Civil Engineering Department as a Lecturer in the same year. He then went to the University of Southampton (UK) in 1964 with a Scholarship and earned his master's degree in advanced structural engineering in 1965 and then $\mathrm{PhD}$ in 1968 working on Shear Wall and Structural Analysis of High Rise Building. As an outcome of his $\mathrm{PhD}$ research he developed a simplified method for analysis of shear walls in tall buildings commonly known as Coull and Choudhury's Method, which has been widely used all over the world. On returning to Bangladesh, he continued to serve as a teacher at BUET. In 1975, he was offered the Commonwealth Staff Fellowship to pursue his post-doctoral studies at the University of Surrey (UK), where he spent a year as a visiting Associate Professor. In 1976, he was appointed as a full Professor of Civil Engineering at BUET. He served as the Head of the Dept. of Civil Engineering, BUET for the periods of 197879 and 1981-83. He also served as the Dean of the Faculty of Civil Engineering during the period of 1983-85. Upon his retirement from BUET in 2001, Prof. Choudhury was appointed as the Vice Chancellor of the BRAC University, Dhaka where he served till 2010. Since 2012, he served as the Vice-Chancellor of the University of Asia-Pacific in Dhaka.

Prof. Choudhury's contribution to infrastructure development of Bangladesh cannot be overstated. Practically no important development project in Bangladesh has been implemented without the involvement of Prof. Choudhury. He acted as expert consultant to a large number of national and international agencies on projects related to expressways, bridges, tall buildings, industrial buildings, transmission towers, aircraft hangars, stadiums, ports and jetties, computerization of public and private sector organizations etc. He was the Team Leader for the Multipurpose Cyclone Shelter 
Program and prepared the master plan for cyclone shelters in the coastal areas of Bangladesh in 1991. He played a vital role in the preparation of the Bangladesh National Building Code (1993), wind speed and seismic zoning maps of Bangladesh. He was one of the members of the Panel of Experts (advising the Government of Bangladesh, the World Bank, Asian Development Bank and OECF, Japan) for the design and construction of Bangabandhu Bridge on the river Jamuna. He was the Chairman of the International Panel of Experts for the design and construction of Padma Multipurpose Bridge. Besides, he was also acting as the chairman of the panel of experts in many other mega projects such as the Dhaka Elevated Expressway (first PPP project in Bangladesh), Karnaphuli Tunnel, Dhaka Subway, Dhaka-Ashulia Elevated Expressway etc.

Prof. Choudhury was a civil engineer, his interest in computers and computer aided design developed during his extensive use of mainframe computer for his $\mathrm{Ph} . \mathrm{D}$ research at the university of Southampton. On his return to BUET from UK he introduced computer programming course in Civil Engineering. He started working with Professor Dr. Abdul Matin Patwari to establish a computer centre at BUET with excellent computing facilities and succeeded in doing so by procuring a mainframe computer, which was the second main frame computer in Bangladesh. Prof. Choudhury also held the position of the Director of Computer Centre for about ten years (1982-1992). Under his leadership, the Computer Center of BUET evolved into a full-fledged computing facility which served the teachers and students as an excellent resource for carrying out research and providing services to outside organizations. The BUET computer centre has later grown into the Institute of Information and Communication Technology (IICT). His contribution to IT sector in Bangladesh is noteworthy. He worked as the chairman of the task force for developing Software Export and IT Infrastructure in Bangladesh from 1997 to 2000 under Ministry of Commerce. He was Convener, Committee on Export of Software and Data Processing Services (1997), Convener, Committee for Formulation of IT Policy for Bangladesh (1999 and 2008), Convener, ICT in Higher Education Group formed by the Ministry of Education (2005). He was a member of the IT Task Force headed by the Hon'able Prime Minister (2001-09). In 2007, he was the Convener, Committee for Preparing Voter List with Photographs. He was a ranking member of the Prime Minister's Task Force on developing Digital Bangladesh.

Because of his popular personality, honesty and neutral public image, Professor Choudhury was appointed Adviser (Minister) in the Non-Party Caretaker Government in April, 1996 and was in charge of the Ministry of Energy and Mineral Resources and the Ministry of Water Resources. Professor Choudhury's popularity and respect among the engineering community of Bangladesh made him the president of the Institution of Engineers, Bangladesh (IEB) for the period of 1992-93 and president of the BUET Alumni Association. Besides such top-tier leadership activities, Prof Choudhury also served as the chairman or head of many other govt. and non-govt. committees and organizations. He was the Chairman of Board of Directors of Bangladesh Shilpa Bank (1996 - 1998), Chairman of the Board of Governors, Bangladesh Institute of Technology, Chittagong (1997-2004), Vice President of the Bangladesh Computer Society, founder President of Bangladesh Earthquake Society etc. He was the Chairman of the Board of Accreditation for Engineering and Technical Education (BAETE), Bangladesh. He was a Fellow of the Institution of Civil Engineers (U.K.) and was a Chartered Engineer, UK and also a Fellow, Institution of Engineers Bangladesh. He was elected Fellow of the Bangladesh Academy of Sciences (1999). He was among the founders of Bangladesh Poribesh Andolon (BAPA), the largest civil society movement in Bangladesh for protection of environment, and was its first President during 2001-2005. As the president of Bangladesh Mathematical Olympiad Committee, he was leading a movement to develop awareness on mathematics among the school and college students of Bangladesh.

Prof. Choudhury proved himself to be a prudent and visionary administrator through many responsibilities he carried out throughout his career. He became Head of the Civil Engineering Department, BUET in the 70s when all the senior teachers of the department left BUET due to somewhat volatile and uncertain socio-economic situation of Bangladesh. He ran the largest 
department of BUET, at one stage, with only 12 junior teachers where he was the only teacher with a $\mathrm{PhD}$ degree. The reputation of the department flourished during his time and relationship between BUET and outside organizations greatly improved. He was very successful as Dean, Faculty of Civil Engineering, Director of Computer center, BUET, Chairman of the Board of Directors of Bangladesh Shilpa Bank, Chairman of the Board of Governors, Bangladesh Institute of Technology, Chittagong, President of the Institution of Engineers, Bangladesh (IEB). As Vice Chancellor of BRAC University and University of Asia-Pacific, he played the leading role in establishing these institutions as top ranking private universities in Bangladesh. He ran the activities of two important ministries of the Government with high reputation as an advisor to the Care-taker Government of Bangladesh.

The works and contributions of Prof. Choudhury to engineering science and technology are reflected in various publications authored by him. He published many papers in international journals and conference proceedings related to tall buildings, low-cost housing, earthquake resistant design, cyclones and storm surges, retrofitting of structures, IT applications and policy issues. His brilliant works will continue to inspire young civil engineers home and abroad.

Dr. Choudhury is the recipient of numerous awards, medals and recognitions. He received Dr. MA Rashid Memorial Gold Medal (1997) by BUET, IEB Gold Medal (1998), Rotary Club Foundation SEED award (2000), Bangladesh Computer Society Gold Medal (2005), ICT Champion Award by Bangladesh Association for Software and IT Services (BASIS, 2009), Lions International (District315) Gold Medal (2007), Khan Bahadur Ahsanullah Gold Medal (2012), Bangladesh Development Initiative (BDI) Lifetime Achievement Award (2017). He received Japan International Cooperation Agency (JICA) Recognition Award in 2013 for his outstanding contribution to Bangladesh's highprofile development schemes. He was awarded the honorary degree of Doctor of Engineering (Honoris Causa) by Manchester University in 2010 - the first person of Bangladeshi origin to receive this honor from a British University. In 2017, he received the prestigious national award Ekuskey Padak for his contribution to science and technology. In recognition to his contribution to the society, Bangladesh Govt. declared him as a National Professor in June 2018. In the same year, he was also adorned with the Order of the Rising Sun: Gold Rays with Neck Ribbon - a highly prestigious honor conferred by the Japanese Government.

Professor Choudhury is survived by his wife Selina Choudhury (a biophysicist) and two bright children. Mrs. Choudhury closely supported his extremely busy professional career. His daughter Charisma F. Choudhury graduated in Civil Engineering from BUET scoring highest CGPA in her class and joined the department of Civil Engineering, BUET as a Lecturer. She completed her Master's and PhD degrees from MIT (USA) and became an Assistant Professor at BUET. Now she is working as an Associate Professor at the Institute for Transport Studies and School of Civil Engineering at the University of Leeds (UK) where she leads the Choice Modelling Research Group. His son Kaashif Reza Choudhury graduated in Electrical Engineering from Wilkes University (USA) and obtained his Master's degree from Virginia Tech.(USA). Kaashif is the Managing Director of KRC Technologies, a company that provides consultancy services for emerging technologies in Dhaka, Bangladesh.

Prof. Choudhury had the rare quality of gentle behavior, sharp memory and helping attitude. He enjoyed the love and respect of thousands of friends and former students, many of whom are in important leadership positions in Bangladesh and across the globe. Bangladesh Academy of Sciences lost a dedicated fellow scientist and the nation lost a great engineer and a patriot citizen with the sad demise of Prof. J R Choudhury in his active career. We pray to the Almighty Allah, Most Gracious and Most Merciful, to grant eternal peace to his departed soul and give strength and courage to the members of his family and friends to bear the loss.

M Feroze Ahmed 